\title{
The influence of farming systems and microbial preparations on the structure of the microbocenosis of the rhizosphere of Triticum aestivum $\mathbf{L}$. \\ Egovtseva A.Yu., Melnichuk T.N., Abdurashitov S.F. \\ Federal State Budget Scientific Institution "Research Institute of Agriculture of Crimea”, Simferopol', Crimea E-mail:eau82@mail.ru
}

Key message. The use of microbial preparations contributed to a change in the taxonomic structure of winter wheat rhizosphere microbiome was established. A more significant effect of microbial preparations was noted under no-till technology on the structure of the microbiome than with the traditional farming system.

Keywords: microbiom, Triticum aestivum L., rhizosphere, complex of microbial preparations, farming systems

Recently, there has been growing interest in the use of complex biological products, which simultaneously include the properties of biological fertilizers and fungicides, which makes it possible to solve many problems of biological plant protection and improve the quality of agricultural products, as well as improve the condition of soils and their fertility. The influence of no-till technology on soil fertility, its properties, and crop productivity requires study and is a very urgent task and helps to increase the sustainability of agroecosystems and preserve the environment. The microbiome of the plant rhizosphere is a living ecosystem and therefore is very plastic, responding to changes in various factors and being a bioindicator of the state of soil biocenosis. The aim of our work was to establish the influence of the complex of microbial preparations (CMP) and farming systems (no-till and the traditional system) on the taxonomic structure of the microbiome of the rhizosphere of Triticum aestivum L. of southern chernozem in the conditions of the Steppe of Crimea. In the research process, modern approaches to studying the taxonomic structure of the rhizosphere microbiome using high-throughput sequencing of 16SrRNA gene libraries were used. A metagenomic analysis of the rhizosphere showed that inoculation with microbial preparations in combination with direct seeding leads to a 2.5 -fold increase compared to the control (1.02\%) of the presence of the genus Flavobacterium. Representatives of this genus are able, along with many functions, to produce a broadspectrum antibiotic on phytopathogens. The share of Rubrobacter, which is an indicator of extreme conditions, decreased by more than 2 times compared with the version without treatment of the CMP (2.90\%). A more significant effect of microbial preparations under no-till conditions on the structure of the microbiome is noted than with the traditional farming system.

\section{Влияние систем земледелия и микробных препаратов на структуру микробоценоза ризосферы Triticum aestivum $\mathbf{L}$.}

Еговиева А.Ю., Мельничук Т.Н., Абдурашитов С.Ф.

Федеральное государственное бюджетное учреждение науки «Научно-исследовательский институт сельского хозяйства Крыма», Симферополь, Крым

\begin{abstract}
Аннотация. Установлено, что применение микробных препаратов способствовало изменению таксономической структуры микробиома ризосферы пшеницы озимой. Отмечено более существенное влияние комплекса микробных препаратов в условиях по-till на структуру микробиома, чем при традиционной системе земледелия.
\end{abstract}

Ключевые слова: микробиом, Triticum aеstivum L., ризосфера, комплекс микробных препаратов, системь земледелия

В последнее время возрос интерес к применению биопрепаратов комплексного действия, одновременно включающих свойства биоудобрений и фунгицидов, что дает возможность решать многие проблемы биологической защиты растений и повышать качество сельскохозяйственной продукции, а также улучшать состояние почв и их плодородие. Влияние технологии no-till на плодородие почвы, ее свойства, на урожайность сельскохозяйственных культур требует изучения и является весьма актуальной задачей, что способствует повышению устойчивости агроэкосистем и сохранению окружающей среды. Микробиом ризосферы растений является живой экосистемой и поэтому является очень пластичной, реагируя на изменения различных факторов и являясь биоиндикатором состояния почвенного биоценоза. Целью нашей работы было установить влияние комплекса микробных препаратов (КМП) и систем земледелия (no-till и традиционная система) на таксономическую структуру микробиома чернозема южного ризосферы Triticum aestivum L. в условиях Степи Крыма. В процессе исследований использованы современные подходы изучения таксономической структуры ризосферного микробиома с использованием высокопроизводительного секвенирования библиотек гена $16 \mathrm{SpPHК.} \mathrm{Метагеномный} \mathrm{анализ} \mathrm{ризосферы} \mathrm{на}$ представленность родов показал, что инокуляция микробными препаратами в сочетании с прямым посевом ведет к увеличению в 2,5 раза по сравнению с контролем (1,02 \%) доли присутствия рода Flavobacterium, представители которого способны наряду с множеством функций продуцировать антибиотик широкого спектра действия на фитопатогены. Доля Rubrobacter, являющаяся индикатором экстремальных условий, снижалась более чем в 2 раза по сравнению с вариантом без обработки КМП (2,90\%). Отмечено более существенное влияние микробных препаратов в условиях no-till на структуру микробиома, чем при традиционной системе земледелия. 